\title{
The Threatening Troika of Populism, Nationalism, and Neoliberalism
}

\author{
Tanya Voss ${ }^{1}$ • Jo Daugherty Bailey ${ }^{2} \cdot$ Jim Ife $^{3} \cdot$ Michaela Köttig $^{4}$ \\ Published online: 22 August 2018 \\ (C) Springer Nature Switzerland AG 2018
}

The idea for this special issue arose out of a meeting of the members of the Council of Social Work Education's Council on Global Social Issues in October 2016. Poised just a week prior to the US Presidential election, some at the meeting bemused the immense support for Donald Trump by conservative leaders and a wide swath of middle- and working-class whites. It was difficult to imagine how someone who regularly and blatantly lied to the public, who had no service record, and publicly used coarse and vulgar language could garner such support. Then-candidate Trump was audio-recorded bragging about sexually assaulting women, and openly and on the record disparaged racial and ethnic minorities, women, American prisoners of war, Muslims and mocked persons with disabilities. What forces were operating in the currents of American political thought and action to allow for such circumstances? What commonalities did this shifting political culture have on the world stage? Are human rights being affected, and if so, how and what are social workers doing? This special issue is the result of such ponderings.

Tanya Voss

tmvoss@mail.utexas.edu

Jo Daugherty Bailey

Jbaile61@msudenver.edu

Jim Ife

j.ife@westernsydney.edu.au

Michaela Köttig

koettig@fb4.fra-uas.de

1 Steve Hicks School of Social Work, The University of Texas at Austin, Austin, TX, USA

2 Metropolitan State University of Denver, Denver, CO, USA

3 Social Work School of Social Sciences and Psychology, Western Sydney University (Parramatta Campus), Parramatta, NSW, Australia

4 Scientific Association of Social Work in Germany, Frankfurt University of Applied Sciences, Frankfurt, Hesse, Germany

\section{Populism}

Trying to whittle down an explanation of populism in a mere few pages and capturing all that has been written and debated about the term seems intellectually irresponsible and practically impossible. The reader who craves greater depth is encouraged to venture into the political science literature on the matter, while knowing that even within that field, the term populism, and which movements are appropriately defined as populist, remains unresolved. From the World Conference "To Define Populism," which set out to specify the concept, in 1967 to present day, no singular clear, cohesive definition has earned agreement among experts (Mudde and Rovira Kaltwasser 2017). Thus, our attempt here is to present a cursory understanding of the term and the movements most commonly defined as populist.

The term populism appears to have originated in late nineteenth century movements in Russia and the USA, respectively, the Narodniki and the People's Party aka the Populist Party (Kuzminski 2008). Although these movements had differences in terms of their organizational structure and the forces they were opposing, both were in reaction to the concentration of power and marginalization of a particular class of people, in these cases - farmers and rural communities. Following these, populist movements bubbled up in South America, Eastern Europe, and Africa throughout the twentieth century.

According to Mudde and Rovira Kaltwasser (2012), populism "is a thin-centered ideology that considers society to be ultimately separated into two homogeneous and antagonistic groups, 'the pure people' and 'the corrupt elite,' and which argues that politics should be an expression of the volonté générale (general will) of the people" (p. 8). Who "the people" are varies according to the movement and, as such, each particular populist movement defines its out-group(s) in terms of those seen as "threats" (which could be from both above, as in those holding political power, and below, as those in other identity groups). Populists claim political legitimacy as they are the representatives of the common people, as opposed to special interests (Canovan 1999). Their mechanization for mobilization often rests on an ideal that they will unite 
the country in a way the current system does not (Canovan 1999). Paradoxically, populist movements claim to represent "our people," oftentimes signifying an "othering" of some ethnic, racial, or immigrant population (Canovan 1999). Such populist movements are decidedly non-pluralistic. "Populists in power invariably fall back on the argument that they are the only morally legitimate representatives of the people and that, furthermore, only some of the people are actually the real, authentic people who are deserving of support and, ultimately, good governance" (Müller 2016, p. 28).

\section{Nationalism}

As with the problems of narrowing a definition of populism, the concept of nationalism is inherently complex. It is at once, a movement, an ideology, a process, and an aspiration (Norman 1999) wherein a narrative of group identity aims to bind a people to each other and to some geo-historicalpolitical space. Anderson (2006) asserts that nationalism is an artifact of modernity, which saw the rise of printcapitalism (allowing commoners with access to the narrative of community) along with the collapse of societies that had members bound together through a sacred ruler. Nationalism is a shifting, fluid phenomenon that emanates from a sense of identity, a sentiment of belonging to a community of likeothers, and a conceptualization of a shared history and culture (Norman 1999). The sentiment of commonality and community is "imagined" or socially constructed (Anderson 2006), serving those within the community with a sense of purpose and meaning. Such meaning and sense of belonging is so strong that members will even sacrifice themselves for the community. "Finally, it is imagined as a community, because, regardless of the actual inequality and exploitation that may prevail in each, the nation is always conceived as a deep, horizontal comradeship. Ultimately it is this fraternity that makes it possible, over the past two centuries, for so many millions of people, not so much to kill, as willingly to die for such limited imaginings" (Anderson 2016, p. 7). Thus, nationalism creates an incredible bond and an intense, and potentially maniacal, following.

\section{Neoliberalism}

Neoliberalism is an economic philosophy that maintains that free, unregulated, and competitive markets are both efficient and socially responsible, producing the greatest good for the greatest number, informed by Classical Liberalism's valuing of free and competitive markets but departing from it in its monetarism and support for a state role in providing legal protections for the system (Thorsen 2011). Neoliberalism stands in renouncement of socialism and Keynesian economics, systems that, according to neo-liberalists, create stagnation and dependency, and ultimately, economic crisis and decay (Thorsen 2011). Under neoliberalism, the state plays a minimal role in the market, allowing for the rationality of investors and consumers to determine the demand, value, and supply of goods and services. Heralded on the world stage by Thatcher and Reagan and promoted by policies of the International Monetary Fund and the World Bank (Steger and Roy 2010), the age of neoliberalism ushered in a new global economy, whereby labor, capital flow, and trade are relatively boundaryless. Proponents argue benefits owing to neoliberal policies, including a rising standard of living in the poorest countries; greater prosperity; and the actualization of individual liberty (Lippmann 1938; Ostry et al. 2016; Steger and Roy 2010). Critics point to the neoliberal failures of the increased concentration of wealth and income concomitant with economic disparity and lack of social mobility; high unemployment; and severe fiscal crises only resolved by government bail-outs (Cahill and Konings 2017; Ostry et al. 2016; Steger and Roy 2010). While the literature is fraught with debate over the merits of neoliberalism, it encompasses the global market and does not appear that any alternative is on the horizon.

\section{Troika}

Troika is a Russian term that refers to the combined forces of three entities to affect control over an outcome and is used here symbolically to illustrate that populism, nationalism, and neoliberalism are, at present, co-occurring phenomena and have a dynamic effect upon each other. Today's populism is ever-increasingly nationalistic and anti-democratic (Müller 2016), with the flare of xenophobia propelling it to a narrowing definition of who "the people" are. For example, "[I] $\mathrm{n}$ Poland and Hungary, populist strongmen have begun to put pressure on critical media, to violate minority rights, and to undermine key institutions such as independent courts (Foa and Mounk 2016, p. 16). Populism has become "... a politics of cultural resentment divorced from any substantive program of political or economic reforms" (McGrath 2013, p. 55). In part, the rise of nationalistic populism is attributable to globalization, with its movement of people and its situating workers in competition with others across the globe, which is inextricably linked to the internationalization of neoliberalist policies.

As neoliberalism has come to dominate the global economy, no nation is exempt from its reach. To play on the international stage, adherence to at least some of its principles is required (e.g., adjusting tariffs or working conditions to align with international law). As production moves from places where labor is expensive (as in, the global north) to places where cheaper labor lives (as in, the global south), workers 
are displaced in the former, and in the latter, traditional ways of living are disrupted, both of which are a formula for dispossession, anger, and resentment. Thus, the dispossessed are ripe for seeking an enemy, some group who can be seen as the cause of their uprooting. Enter nationalistic populism, which in the west, offers an answer that will not necessarily disrupt the neoliberalist agenda, and in the south, may portend, but none are entirely independent from the effects of the global marketplace.

Our contributors provide perspective, enhance our understanding of, and suggest meaningful social work responses as they bear witness to the impact the rise of these phenomena on our world and its most vulnerable members.

Noble begins by addressing how a "culture of hyper-productivity, anti-humanist populism and authoritarian welfare" erodes the human rights framework underpinning social work. She goes on to focus on social work's more progressive stance and draws on mistakes from 12 years of Nazi rule in Germany to distill lessons applicable today. From Australia, Ife echoes Noble's cautionary examples and explores right-wing populism and its commonalities with social work. He enjoins social work to view the differences between values in both camps realistically and to move beyond rational argument to effectively engage with the emotions fueling the divergence.

From Brazil and the Philippines, Santana and Esperido both give specific and sometimes brutal examples demonstrating how neoliberal policies and nationalistic populism have rolled back the advancement of human rights, reduced the minimum worker benefits, and increased governmentendorsed violence against its own citizens.

In the context of nationalistic neoliberal policies, Sluytman shares the results of a qualitative research study examining the responses of communities in a US metropolis when citizens who were formerly incarcerated seek to return. Public attention and support to increase institutional resources to meet basic needs is limited in the face of the reemergence of populist and nationalist discourse which heightens the separation of "deserving" and "undeserving" poor. The author outlines reframing advocacy and calls for renewed community organizing.

Finally, Blum et al. provide case examples calling for social workers to reflect thoughtfully on their individual motivations and roles in choosing to work countering right-wing violence either in education and policy or in direct work with perpetrators, victims, and their families.

It is dangerous to believe that the arc of the moral universe bends toward justice without our actions. Individually and collectively, social workers are called to bear witness to and to act on behalf of social development, cohesion, and empowerment. The rising threats to social justice, human rights, collective responsibility, and respect for diversity (International Federation of Social Workers 2018) mean that social work has an obligation to respond if ours is to be the force for change we claim to be. We hope that this collection of articles serves to spur greater conversation and action by social workers to help promote, protect, and secure rights for all.

\section{References}

Anderson, B. (2006). Imagined communities: reflections on the origin and spread of nationalism (Rev. ed.). London; New York: Verso.

Cahill, D. \& Konings, M. (2017). Neoliberalism. Cambridge, UK; Malden, MA: Polity Press. Retrieved from ProQuest Ebook Central, http://ebookcentral.proquest.com/lib/cudenver/detail. action? docID $=5018405$.

Canovan, M. (1999). Trust the people! Populism and the two faces of democracy. Political Studies, 47, 2-16.

Foa, R., \& Mounk, Y. (2016). The democratic disconnect. Journal of Democracy., 27(3), 27.5-27.2717. https://doi.org/10.1353/jod. 2016.0049.

International Federation of Social Workers (2018). Global definition for social work. Retrieved from https://www.ifsw.org/what-is-socialwork/global-definition-of-social-work/

Kuzminski, A. (2008). Fixing the system: a history of populism, ancient and modern. NY: Continuum Books Retrieved from https:// ebookcentral.proquest.com.

Lippmann, W. (1938). The good society. Boston: Little, Brown \& Co..

McGrath, M. (2013). The histories of populism. National Civic Review, 102(2), 50-56. https://doi.org/10.1002/ncr.21125.

Mudde, C., \& Rovira Kaltwasser, C. (2012). Populism and (liberal) democracy: a framework for analysis. In C. Mudde \& C. Rovira Kaltwasser (Eds.), Populism in Europe and the Americas (pp. 113-136). Cambridge: Cambridge University Press.

Mudde, C., \& Rovira Kaltwasser, C. (2017). Populism: a very short introduction. Oxford: Oxford University Press ISBN 978-0-19023487-4.

Müller, J. W. (2016). What is populism? Philadelphia: University of Pennsylvania Press.

Norman, W. (1999). Theorizing nationalism: first steps. In R. Beiner (Ed.), Theorizing nationalism (pp. 51-66). Albany, NY: SUNY Press.

Ostry, J., Loungani, P., \& Furceri, D. (2016). Neoliberalism: Oversold? Finance and Development, 53(2). Washington: International Monetary Fund. Retrieved online http://www.imf.org/external/ pubs/ft/fandd/2016/06/ostry.htm. Accessed 21 June 2018.

Steger, M. B., \& Roy, R. K. (2010). Neoliberalism: a very short introduction. Oxford: Oxford University Press.

Thorsen, D. E. (2011). The neoliberalism challenge: what is neoliberalism? Contemporary Readings in Law and Social Justice, 2(2), 188 214. 